\title{
Combustion Analysis of Ammonia Fueled High Compression Ratio SI Engine with Glow Plug and Sub-Chamber
}

\author{
- Effects of Ammonia Content under Condition of Co-combustion with Gasoline/Ammonia/Air -
}

Bin Guo ${ }^{1)}$ Mitsuhisa Ichiyanagi ${ }^{1)}$ Kento Kajiki $^{\text {1) }}$ Narumi Aratake ${ }^{1)}$ Qinyue Zheng ${ }^{1)}$

\author{
Masashi Kodaka $^{1)}$ Takashi Suzuki $^{1)}$ \\ 1) Sophia University \\ 7-1 Kioi-cho, Chiyoda-ku, Tokyo 102-8554, Japan (E-mail: suzu-tak@sophia.ac.jp)
}

Received on September, 14, 2021

\begin{abstract}
Ammonia is a kind of energy carrier of hydrogen, and its use as engine fuel has been studied. However, it requires overcoming shortcomings of low combustion speed. We focus that the laminar combustion velocity of gasoline mixture with an excess air ratio at 2.0 is the same as that of ammonia. The combustion of ammonia was simulated by using gasoline experiments under lean-burn conditions and the experimental engine with the sub-chamber and the glow plug. Through experiments, data such as the optimal ignition angle and NOx emissions during lean combustion are obtained. Based on the above experimental data, authors did the co-combustion experiment of gasoline/ammonia/air. Under the conditions of excess air ratio of $1.1,1.2,1.3$, maximum ammonia content is $33 \% \mathrm{NH}_{3}$, the engine could be operated with less than $10 \%$ variation in IMEP.
\end{abstract}

KEY WORDS: Heat Engine, Fuel/Alternative Fuel, Combustion Analysis, Ammonia, High Compression Ratio, Sub-chamber (A1)

\section{Introduction}

At present, with the widespread use of internal combustion engines (SI engine and CI engine) the issue of global warming is becoming more serious. In order to solve the environmental issues caused by automobiles, strict fuel economy regulations are being enforced in many countries. On the other hand, fuel cell vehicle and electric vehicle technology are accelerated research. However, from the viewpoint of Well-to-Wheel, electric vehicles cannot essentially solve the problem of global warming ${ }^{(1)}$. This is because the electricity used by electric vehicles still mainly comes from thermal power plants. According to the investigation by the Agency for Natural Resources and Energy of Japan, for the whole year of 2020 , thermal power generation accounted for $82.6 \%$ of the total power generation ${ }^{(2)}$. Therefore, in order to achieve zero carbon emissions in the true sense, hydrogen is a good alternative energy source. Although hydrogen-fueled engine vehicles and fuel cell vehicles have been successfully developed, the transportation and storage costs of hydrogen ${ }^{(3)}$, and hydrogen embrittlement ${ }^{(4)}$ still limit the popularization of hydrogen fueled vehicles. On the other hands, ammonia is also a carbon-free fuel. At room temperature (298 K), ammonia gas can be liquefied under $1 \mathrm{MPa}$, and the energy density of liquid ammonia under this condition is 11.21 $\mathrm{MJ} / \mathrm{L}$. In contrast, at room temperature, hydrogen is still gaseous at a pressure of $20 \mathrm{MPa}$, and the energy density at this time is 1.9 $\mathrm{MJ} / \mathrm{L}^{(3)}$. Which means, compared with hydrogen, the cost of ammonia in storage and transportation is relatively small. In addition, ammonia, as an important industrial raw material, has been used for nearly 100 years, which means that ammonia has a more mature production technology. In 2019, the team at the University of Tokyo developed a highly active catalyst for the synthesis of ammonia under normal temperature and pressure conditions ${ }^{(5)}$. In the future, the production cost of ammonia is expected to be even lower. Based on the above reasons, authors conduct research with the goal of developing an ammonia engine.

On the other hand, using ammonia as engine fuel still has some obvious issues. Such as, toxicity ${ }^{(6)}$, corrosive to copper alloys $^{(7)}$, NOx emissions, high auto-ignition temperature, low laminar burning velocity (compared with fossil fuels), etc. Our research focused on poor engine performance caused by ammonia's low combustibility. The laminar burning velocity of ammonia is about $7 \mathrm{~cm} / \mathrm{s}^{(8)(9)}$, which is roughly the same as the laminar burning velocity of gasoline under lean combustion conditions ${ }^{(10)}$. Therefore, in the first phase of this research, lean combustion condition for gasoline was chosen, and used to understand the general trend of ammonia combustion characteristics in SI engine. Based on past research, increasing the temperature in the sub-chamber is beneficial to the initial combustion $^{(11)}$. For SI engines with sub-chambers, the jet from the sub-chamber was proved to promote combustion ${ }^{(12)}$. Based on the above lean combustion experimental data, authors did the cocombustion experiments of gasoline/ammonia/air.

\section{Experiment Apparatus and Conditions}

\subsection{Experimental apparatus}




\section{Bin Guo et al. / International Journal of Automotive Engineering}

Vol.13, No.1(2022)

In this experiment, a water-cooled horizontal single-cylinder diesel engine (YANMAR TF120V) was selected as the prototype, due to its high compression ratio, it is beneficial for experiments of lean conditions and co-combustion experiments of gasoline/ammonia/air. Then removed the injector of the original diesel engine, processed the cylinder head, and installed the spark plug with an adapter.

The engine specification is shown in Table 1. As described above, the spark plug was installed on the top of the sub-chamber through an adapter, and on the side of the spark plug is the glow plug (NGK-SRM). Gasoline injector (BOSCH INJ-035) and ammonia injector (Nikki O-RING type) are installed in the intake port. A pressure sensor (Kistler 5018A) was installed in the main chamber. The piston diameter of the engine is $92 \mathrm{~mm}$, and the stroke is $96 \mathrm{~mm}$, the engine displacement is $638 \mathrm{cc}$, while the subchamber is $23.5 \mathrm{cc}$, accounting for about $3.7 \%$ of the total. The main chamber and sub-chamber are connected by an orifice with a cross-sectional area of $52.6 \mathrm{~mm}^{2}$. The compression ratio of the engine is 17.7 .

Table 1 Engine specifications.

\begin{tabular}{|l|l|}
\hline Engine & $\begin{array}{l}\text { Water-cooled horizontal } \\
\text { single cylinder }\end{array}$ \\
\hline Sub-chamber & Spherical swirl with glow plug \\
\hline Valve mechanism & Overhead valve \\
\hline Ignition method & Spark ignition \\
\hline Fuel supply & Port injection \\
\hline Type of aspiration & Natural aspiration \\
\hline Total displacement $[\mathrm{cc}]$ & 638 \\
\hline Sub-chamber displacement $[\mathrm{cc}]$ & 23.5 \\
\hline Bore [mm] $\times$ Stroke $[\mathrm{mm}]$ & $92 \times 96$ \\
\hline Number of orifices $[\mathrm{n}]$ & 1 \\
\hline Cross-sectional area of orifice $\left[\mathrm{mm}^{2}\right]$ & 52.6 \\
\hline Compression ratio [-] & 17.7 \\
\hline
\end{tabular}

Figure 1 shows the schematic diagram of the entire experimental equipment in this study. The engine is connected to the eddy current dynamometer through an electromagnetic clutch to stabilize the engine speed. The throttle valve is controlled by hand to obtain a constant intake pressure, which is measured by the intake manifold pressure sensor. And the signal for the intake pressure is sent to the general-purpose ECU (INFINITY SERIES7). Fuel injection quantity (gasoline and ammonia), injection timing and ignition timing are controlled by the ECU. Fuel injection signal and ignition signal are also transmitted to the data logger at the same time. In the co-combustion experiment, the injection ratio of gasoline and ammonia is also controlled by the ECU. The signal sent by a rotary encoder (E6B2-CWZ6C) every two revolutions of the crankshaft is sent to the ECU, to match the TDC (top dead center) time of the piston compression stroke to determine the realtime position of the piston in the combustion experiment. The signals from the oxygen and NOx sensor (HORIBA MEXA-720) located in the exhaust pipe are transmitted to the data logger. The temperature of the engine coolant water is controlled by the coolant water system (consists of a coolant heater, a heat exchanger, and a pump), and the temperature information of the coolant water is passed to the ECU. A catalyst is installed on the way of the exhaust pipe. The catalyst is heated to over $300^{\circ} \mathrm{C}$ by the catalyst heater to purify the unburned ammonia gas in the co-combustion experiment.

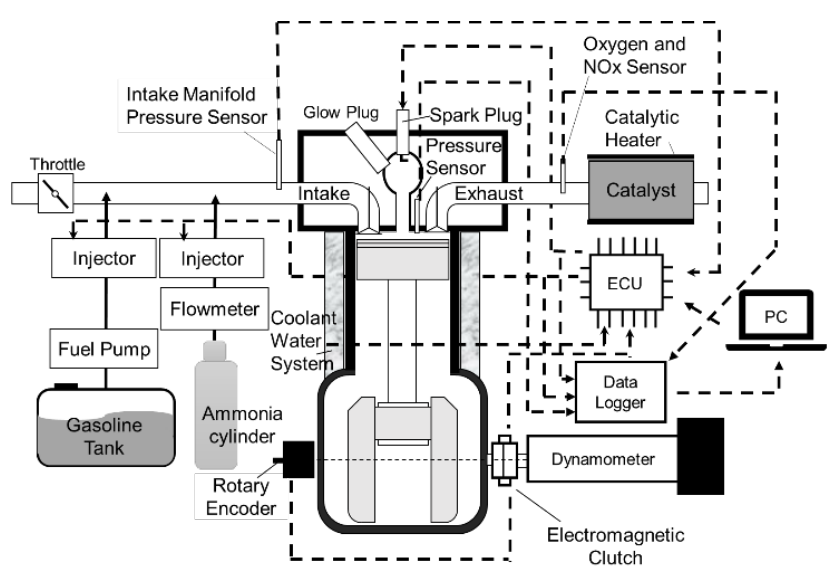

Fig. 1 Schematic of the overall experimental apparatus.

\subsection{Experimental Method}

The experiment data were recorded when the engine speed was stable. The in-cylinder pressure was recorded for 100 cycles for every $1 \mathrm{deg}$. crank angle. Averaged the in-cylinder pressure data of 100 cycles, and then calculated the heat release rate, IMEP, thermal efficiency, etc. The data of oxygen content and NOx content in exhaust gas are the average of $720 \mathrm{deg} . \times 100$ cycles.

\subsection{Experimental Conditions}

\subsubsection{Lean combustion experiment}

The detailed experimental conditions for the lean combustion are shown in Table 2 . The engine speed was controlled by the eddy current dynamometer at $1000 \mathrm{rpm}$. The ignition timing was set from 10 to $-2 \mathrm{deg}$. BTDC. The engine coolant water temperature was controlled at $45^{\circ} \mathrm{C}$. When the engine was running, the intake pressure was controlled by the throttle valve, and stabilized at around $99 \mathrm{kPa}$. The intake temperature was $25{ }^{\circ} \mathrm{C}$ at room temperature. The gasoline and air mixture gas temperature in the sub-chamber was controlled by the voltage of the glow plug. In the experiment, the voltage of the glow plug was divided into 5 levels, respectively $0 \mathrm{~V}, 5 \mathrm{~V}, 6 \mathrm{~V}, 8 \mathrm{~V}$, and $10 \mathrm{~V}$. Regarding the adjustment of the excess air ratio in the experiment since the actual excess air ratio is related to the actual operating state of the engine, and has some differences with the input value through the ECU. Therefore,

Table 2 Experimental condition for lean combustion

\begin{tabular}{|l|l|}
\hline Engine RPM [rpm] & 1000 \\
\hline Fuel $[-]$ & Gasoline \\
\hline Injection timing $\left({ }^{\circ} \mathrm{CA}\right)$ & -30 \\
\hline Ignition timing $[\mathrm{deg} . \mathrm{BTDC}]$ & $10 \sim-2$ \\
\hline Coolant temperature $\left[{ }^{\circ} \mathrm{C}\right]$ & 45 \\
\hline Intake pressure $[\mathrm{kPa}]$ & 99 \\
\hline Intake air temperature $\left[{ }^{\circ} \mathrm{C}\right]$ & 25 \\
\hline Glow plug voltage $[\mathrm{V}]$ & $0,5,6,8,10$ \\
\hline Excess air ratio $[-]$ & 1.82 \\
\hline
\end{tabular}




\section{Bin Guo et al. / International Journal of Automotive Engineering}

Vol.13, No.1(2022)

the excess air ratio $(\lambda)$ calculated based on the oxygen content in the exhaust gas was used as the experiment condition. The measured excess air ratio in the experiment is 1.82 .

\subsubsection{Co-combustion experiment}

The detailed conditions for the co-combustion experiments are shown in Table 3. Same with the lean combustion experiment, the engine speed was set at $1000 \mathrm{rpm}$. The injection timings for both gasoline and ammonia were set at $30 \mathrm{deg}$. BTDC (criteria: exhaust stroke TDC). The ignition timing was set to 0 deg. BTDC. The conditions of coolant temperature, intake pressure and intake air pressure were the same with the lean combustion experiment For glow plug voltage conditions, unlike the lean combustion experiment of gasoline, it only compared the combustion under the glow plug voltage at $0 \mathrm{~V}$ and $10 \mathrm{~V}$. The injection ratio of gasoline and ammonia is defined as follows. Under the condition that the engine takes in a certain amount of air and the excess air ratio is the same, if all the air is used for gasoline combustion, the injection ratio is defined as $100 \%$ gasoline. If $90 \%$ of the air is used for gasoline combustion, $10 \%$ is used for ammonia combustion, the defined injection ratio is $90 \%$ gasoline - $10 \%$ ammonia, and so on. For these experiments, the injection ratios were $100 \%$ Gas $\left(0 \% \mathrm{NH}_{3}\right), \quad 93 \% \mathrm{Gas}_{-} 7 \% \mathrm{NH}_{3} \quad\left(7 \% \mathrm{NH}_{3}\right), \quad 87 \% \mathrm{Gas} \_13 \% \mathrm{NH}_{3}$ $\left(13 \% \mathrm{NH}_{3}\right), \quad 80 \% \mathrm{Gas} \_20 \% \mathrm{NH}_{3} \quad\left(20 \% \mathrm{NH}_{3}\right), \quad 73 \% \mathrm{Gas} \_27 \% \mathrm{NH}_{3}$ $\left(27 \% \mathrm{NH}_{3}\right)$, and $67 \% \mathrm{Gas} \_33 \% \mathrm{NH}_{3}\left(33 \% \mathrm{NH}_{3}\right)$. The excess air ratio conditions were $1.1-1.3$. It is worth noting that under the condition of $60 \% \mathrm{Gas} \quad 40 \% \mathrm{NH}_{3}\left(40 \% \mathrm{NH}_{3}\right)$, when the excess air ratio is 1.3 , the COV (IMEP) is greater than $10 \%$ (unstable), so the results of this condition are not discussed in this study.

Table 3 Experimental condition for co-combustion

\begin{tabular}{|l|l|}
\hline Engine RPM [rpm] & 1000 \\
\hline Fuel for injector 1 [-] & Gasoline \\
\hline Fuel for injector $2[-]$ & Ammonia \\
\hline Injection timing $\left[{ }^{\circ} \mathrm{CA}\right]$ & -30 \\
\hline Ignition timing $[$ deg. $\mathrm{BTDC}]$ & 0 \\
\hline Coolant temperature $\left[{ }^{\circ} \mathrm{C}\right]$ & 45 \\
\hline Intake pressure $[\mathrm{kPa}]$ & 99 \\
\hline Intake air temperature $\left[{ }^{\circ} \mathrm{C}\right]$ & 25 \\
\hline Glow plug voltage $[\mathrm{V}]$ & 0,10 \\
\hline Injection ratio (bass on ammonia) $[\%]$ & $0,7,13,20,27,33,(40)$ \\
\hline Excess air ratio $[-]$ & $1.1,1.2,1.3$ \\
\hline
\end{tabular}

\subsection{Evaluation Method}

The power of the engine can be characterized by IMEP. IMEP $P_{m i}(\mathrm{MPa})$ can be calculated by equation (1), and the discrete form of this equation (2) is used in the data processing.

$$
\begin{aligned}
& P_{m i}=\frac{1}{V_{s}} \cdot \oint P d V \\
& P_{m i}=\frac{1}{V_{s}} \cdot \sum_{j=0}^{n-1} \frac{P_{j+1}+P_{j}}{2} \cdot\left(V_{j+1}-V_{j}\right)
\end{aligned}
$$

where $V_{S}(\mathrm{cc})$ is the stroke volume and $\mathrm{P}(\mathrm{MPa})$ is the in-cylinder pressure.

The stability of combustion can be characterized by the coefficient of variation (COV) of IMEP. The COV(IMEP) can be expressed by the following equation:

$$
\operatorname{COV}(I M E P)=\frac{\sigma_{P_{m i}}}{\overline{P_{m i}}} \cdot 100 \%
$$

where $\sigma_{P_{m i}}(\mathrm{MPa})$ is the standard deviation of IMEP. $\overline{P_{m l}}(\mathrm{MPa})$ is the average of the IMEP. If the COV(IMEP) is less than $10 \%{ }^{(13)}$, the combustion is considered stable.

To calculate the indicated thermal efficiency of the engine, the indicated power of the engine needs to be calculated first. The indicated power $P_{i}(\mathrm{~kW})$ can be calculated by the following equation:

$$
P_{i}=\frac{P_{m i} \cdot A \cdot S \cdot n \cdot Z \cdot i}{600}
$$

where $\mathrm{A}\left(\mathrm{cm}^{2}\right)$ is the cylinder cross-sectional area, $\mathrm{S}(\mathrm{m})$ is the piston stroke, $\mathrm{n}(\mathrm{min}-1)$ is the engine rpm, $\mathrm{Z}(-)$ is the number of cylinders, and $i(-)$ is the constant number, and $i$ equal to $1 / 2$ for $4-$ stroke engine.

The indicated thermal efficiency $\eta_{i}(\%)$ of the engine can be calculated by the following equation:

$$
\eta_{i}=\frac{k \cdot P_{i}}{\sum_{i=1}^{i=n}\left(F_{i} \cdot H_{u i}\right)}
$$

where $\mathrm{k}(\mathrm{kJ} / \mathrm{kWh})$ is a constant number equal to $3600, \mathrm{~F}(\mathrm{~kg} / \mathrm{h})$ is the fuel consumption, and $H_{u}(\mathrm{~kJ} / \mathrm{kg})$ is the lower calorific value for fuel, when the fuel is gasoline, the value is 42280 , when the fuel is ammonia, the value is 18600 .

The combustion speed is evaluated by the percentage of fuel burned per unit crankshaft angle. Fuel consumption is calculated from the injection duration of each fuel injector. NOx emission is evaluated by experimentally measured NOx content (ppm).

\section{Results and Discussion}

\subsection{Results for Lean Combustion Experiments}

3.1.1. Influence of ignition timing and glow plug voltage on IMEP and indicated thermal efficiency

The influence of glow plug voltage and ignition timing on IMEP is shown in Fig. 2, and indicated thermal efficiency of combustion is shown in Fig. 3. Regardless of the conditions of the glow plug voltage, both IMEP and indicated thermal efficiency show an increase tend firstly, while the ignition timing is retarded. IMEP and indicated thermal efficiency reach the maximum value when the ignition timing is near the TDC $(1 \mathrm{deg}$. BTDC or 0 deg. BTDC). Afterward both IMEP and indicated thermal efficiency decrease with the delay of ignition timing. Based on the ignition timing when IMEP and thermal efficiency are the maximum value, when the ignition timing is advanced, the combustion of the fuel in the sub-chamber is advanced. Due to the high compression ratio of the engine used in the experiment, the pressure in the main combustion chamber is high at this time, caused a pressure loss at 


\section{Bin Guo et al. / International Journal of Automotive Engineering}

Vol.13, No.1(2022)

the vicinity of the orifice between sub-chamber and main chamber, which makes it difficult for combusted mixture to flow into the main chamber. This leads to a decrease in IMEP and indicated thermal efficiency caused by the advance of the ignition timing. Ignition after the ignition timing of the maximum IMEP and indicated thermal efficiency will also cause a decrease in IMEP and thermal efficiency. This is due to the drop in pressure and temperature in the main chamber caused by the downward movement of the piston, and makes the incomplete combustion, resulting in IMEP and indicated thermal efficiency decreased. And when the excess air coefficient is 1.82 , ignition at -3 deg. BTDC and later caused the engine to misfire and caused it to malfunction.

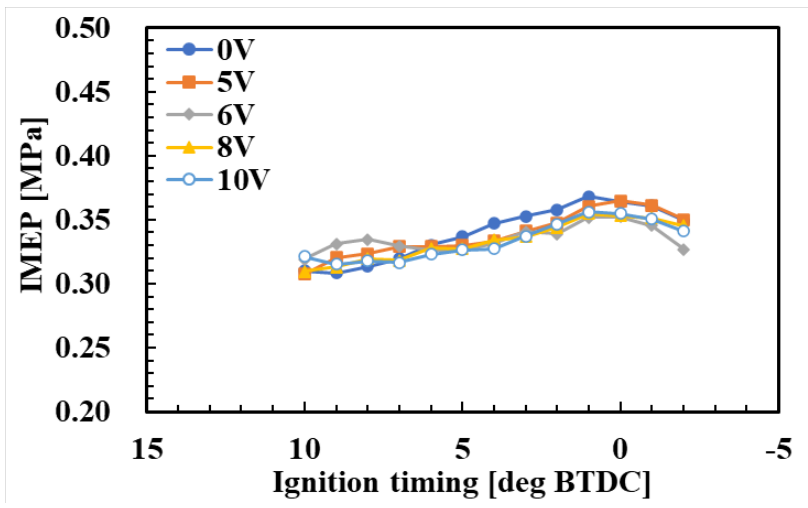

Fig. 2 Influence of the ignition timing and the glow plug voltage on $\operatorname{IMEP}(\lambda=1.82)$

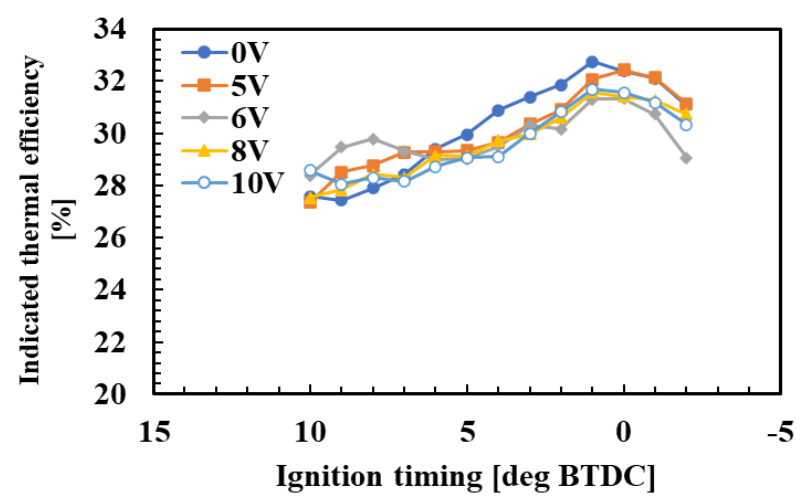

Fig. 3 Influence of the ignition timing and the glow plug voltage on indicated thermal efficiency $(\lambda=1.82)$

In Figs. 2 and 3, the different colored curves represent different glow plug voltage conditions. It can be seen from the figures that with the increase of the glow plug voltage, the IMEP and thermal efficiency have not improved significantly, under the condition of ignition time retarded less than $5 \mathrm{deg}$. BTDC. Due to the high compression ratio of the engine used in the experiment, under the condition of ignition time retarded less than $5 \mathrm{deg}$. BTDC, the temperature and pressure in the combustion chamber at the time of ignition is high enough. At those conditions, due to the high temperature of the glow plug, a small amount of mixture around the glow plug is auto ignited during the compression stroke, resulting in a decrease in the IMEP, which in turn leads to a decrease in indicated thermal efficiency. Under the condition of ignition timing advanced more than 5 deg. BTDC, the IMEP and thermal efficiency are higher when the glow plug is used. The reason is considered to be that the temperature at the time of ignition in the combustion chamber is low. Thus, under those conditions, with using the glow plug, the IMEP and thermal efficiency become better than without the glow plug.

3.1.2. Influence of ignition timing on combustion period and ignition delay

It is generally believed that the combustion period of SI engines is about 26 deg., and the combustion period (10 to 90 of mass fraction burned) of HCCI engines is about $8 \mathrm{deg} .^{(14)}$. By combing sub-chamber with high compression ratio, the combustion period is shortened as shown in Fig. 4. As shown in the figure, the ignition delay ( 0 to 10 of mass fraction burned) hardly changes under the condition of ignition timing from $10 \mathrm{deg}$. BTDC to 2 deg.BTDC. And the ignition delay is increased from $1 \mathrm{deg}$. BTDC, whose reason can be divided into two parts. When the ignition timing is $1 \mathrm{deg}$. BTDC and $0 \mathrm{deg}$. BTDC, the piston position is near or at TDC, and the turbulence in the sub-chamber is decreased as the flow from the main chamber into the sub-chamber is decreased. This leads to an increase in the ignition delay. When the ignition timing is -1 deg. BTDC and -2 deg. BTDC, the piston is in the downward stroke. This makes the temperature and pressure drop in the sub-chamber, which gives to increase the ignition delay.

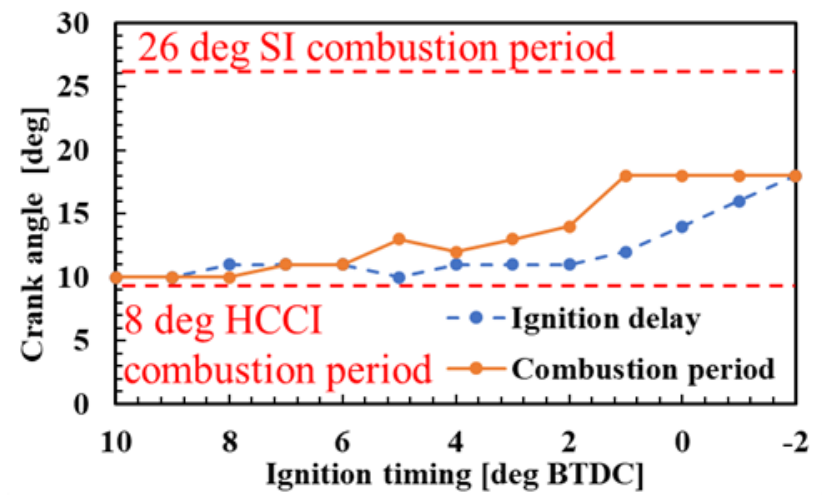

Fig. 4 Influence of the ignition timing on ignition delay and combustion period $(\lambda=1.82$, glow plug voltage: $0 \mathrm{~V})$

With the ignition timing is retarded, the combustion period shows a slow increase trend, under the condition of ignition timing is advanced more than $2 \mathrm{deg}$. BTDC. Between the condition of ignition timing $2 \mathrm{deg}$. BTDC and $1 \mathrm{deg}$. BTDC, the combustion period increased significantly and then remained almost unchanged. The combustion period mainly depends on the fuel combustion in the main combustion chamber. As shown in Fig.4, the combustion period is shorter than the conventional SI engine combustion period. It can be inferred, the ejection from the sub-chamber causes the unburned gas in the main chamber self-ignition or multi-point ignition. But as the ignition timing is delayed, the pressure in the main chamber at the beginning of combustion continues to decrease, which makes the combustion period increase under the condition of between 10 to $1 \mathrm{deg}$. BTDC. The position of the piston when the combustion starts in the main chamber under the conditions of ignition time from $1 \mathrm{deg}$. BTDC is around 10 degree advanced from TDC. Therefore, the turbulence strength in the main chamber become strong by the burned gas jet from the sub-chamber and it makes easy to self-ignite or multi-point ignite. The positive effect of turbulence on multi-point ignition is greater than the negative effect of pressure decreases on combustion. As a result, it 


\section{Bin Guo et al. / International Journal of Automotive Engineering}

Vol.13, No.1(2022)

is considered that the combustion period is unchanged when the ignition time is after 1deg. BTDC. In conclusion, by combining the sub-chamber structure and high compression ratio, the combustion period of the SI engine can be greatly shortened. For $\lambda=1.82$, the MBT combustion period is $30.7 \%$ shorter than that of the conventional SI engine.

3.1.3. Influence of ignition timing and glow plug voltage on $\mathrm{NOx}$ emission

Since gasoline almost does not contain nitrogen, all NOx in the exhaust gas belongs to the thermal NOx, which is generated by the reaction of nitrogen and oxygen in the air in a high-temperature environment. It can be seen from Fig. 5, with the ignition timing is retarded, NOx emission is significantly reduced. When igniting at $1 \mathrm{deg}$. BTDC and later, the downward trend of NOx emissions slows down. As explained before, with the ignition timing is retarded, the combustion period is gradually extended, hence the maximum temperature in the combustion chamber decreases, so thermal NOx emission is reduced.

Similarly, it can be seen from Fig. 5 the difference in the glow plug voltage has little effect on NOx under the condition of ignition timing retarded less than $5 \mathrm{deg}$. BTDC, and the difference in NOx emissions due to different glow plug voltages is more obvious at ignition timing advanced more than $5 \mathrm{deg}$. BTDC. And as shown in Fig.4, when the ignition timing advanced more than 5 deg. BTDC, the ignition delay is about 10 degrees, and when the ignition timing retarded less than $5 \mathrm{deg}$. BTDC, the range of ignition delay is from 10 to 18 degrees. This means the piston position when the combustion starts in the main chamber (mass fraction burned $10 \%$ to $90 \%$ ) is near to the TDC, and mixture gas in the main chamber has a higher temperature under the condition of ignition timing advanced more than $5 \mathrm{deg}$. BTDC. With the ignition timing is retarded, combustion temperature decreases, and cause NOx emission decreases exponentially, as shown in Fig. 5. According to past research ${ }^{(15)}$, thermal NOx emission and temperature have an exponential relationship. Thus, under the experimental conditions with higher temperature during ignition (ignition timing advanced more than 5 deg. BTDC), a small temperature rise caused by glow plug will cause a relatively significant increase in NOx emission.

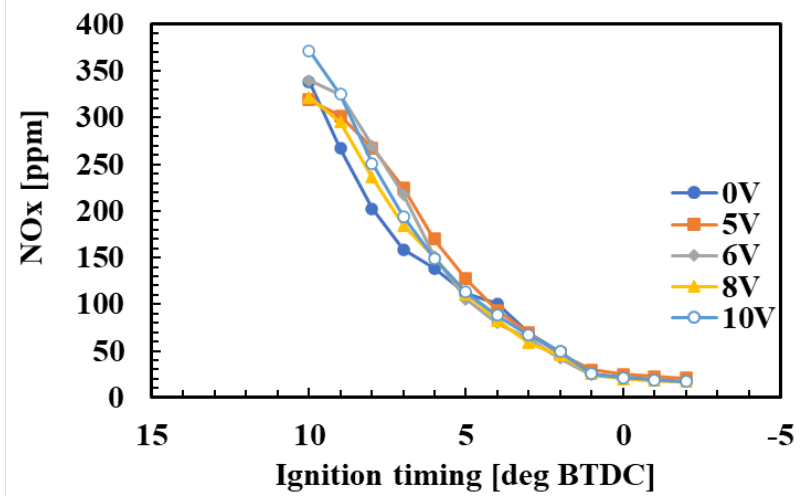

Fig. 5 Influence of the ignition timing and the glow plug voltage on NOx emission $(\lambda=1.82)$

\subsection{Results for Co-combustion Experiments}

3.2.1. Influence of gasoline and ammonia mixture ratio on combustion

Since the mass energy density of gasoline is greater than that of ammonia, the total fuel energy will decrease as the proportion of ammonia increases (gasoline decreases) while maintaining a certain excess air ratio, as shown in Fig. 6.

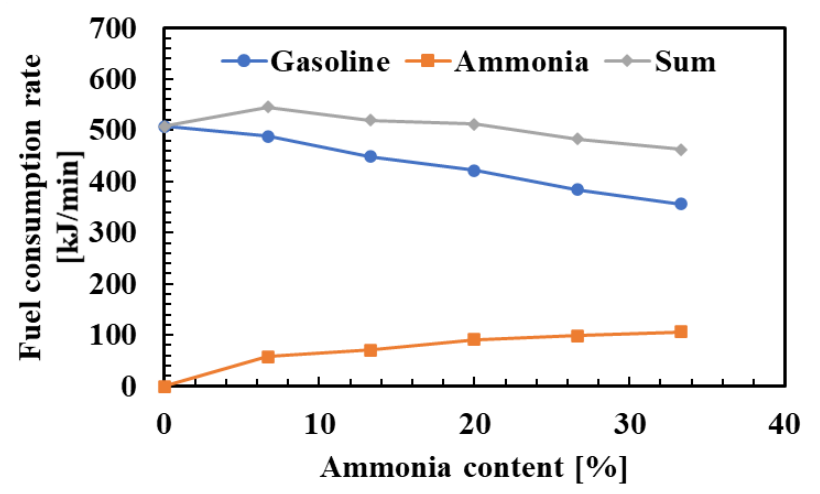

Fig. 6 Variation in actual fuel consumption rate under the condition of different gasoline/ammonia mixture ratio $(\lambda=1.3$, glow plug voltage: $0 \mathrm{~V}$, ignition timing: $0 \mathrm{deg}$. BTDC)

Different gasoline/ammonia mixture ratios result in different total fuel energy, and the effect on the internal pressure of the cylinder after combustion is shown in Fig. 7. It can be seen from the figure that under the same ignition time condition, as the amount of ammonia in the fuel increases, the second peak pressure of the in-cylinder pressure gradually decreases, and the second peak pressure occurs gradually delayed. There are two main reasons for the decrease in combustion peak pressure, 1st is the reduction of the total fuel energy, 2 nd is the influence of the combustion speed.

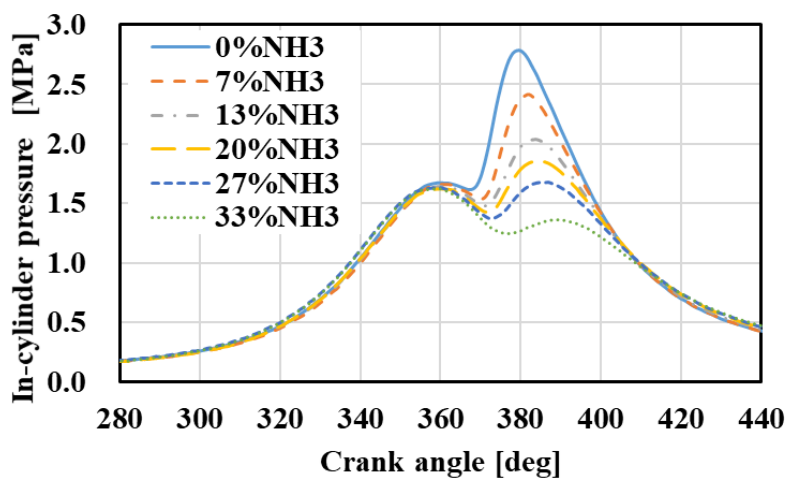

Fig. 7 Influence of gasoline and ammonia mixture ratio on incylinder pressure ( $\lambda=1.3$, glow plug voltage: $0 \mathrm{~V}$, ignition timing: 0 deg. BTDC)

Figure 8 shows the effect of gasoline and ammonia mixture ratio on the mass fraction burned, that is, the effect on the combustion speed. It can be seen from the figure, as the amount of ammonia in the fuel increases, the slope of the curves gradually decreases, which means a decrease in combustion speed. As the combustion speed slows down, the overall combustion period becomes longer. This is also the reason for the decrease in the peak combustion pressure in Fig 7. It can also be seen from Fig. 8 that as the ammonia content increases, the rising time of the curve is 
also be delayed. This is also because the increase in the proportion of ammonia in the fuel causes the flame core to grow slower after the ignition.

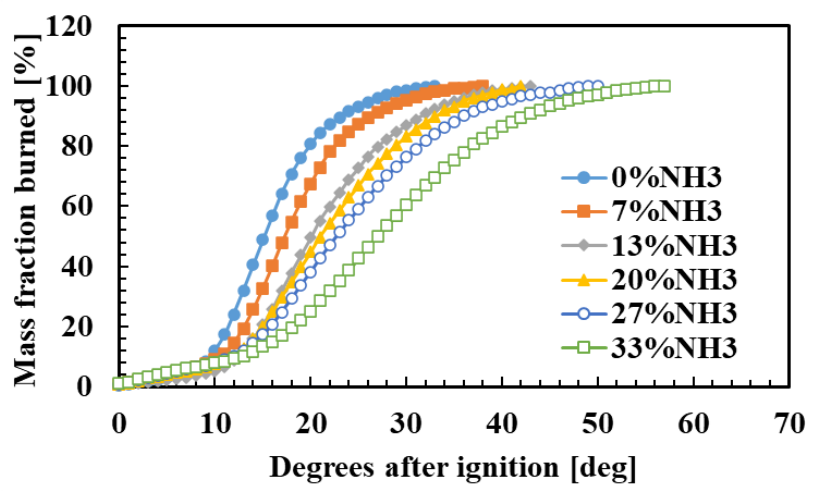

Fig. 8 Influence of gasoline and ammonia mixture ratio on mass fraction burned $(\lambda=1.3$, glow plug voltage: $0 \mathrm{~V})$

The influence of glow plug voltage and gasoline and ammonia mixture ratio on IMEP is shown in Fig. 9. As shown in the figure, with the increase of ammonia content, the curve of both glow plug voltage conditions shows almost a decreased tendency. And under the conditions with relatively high ammonia content $(27 \%, 33 \%)$, by using the glow plug, IMEP can be improved in comparison without glow plug. This is because the temperature of the glow plug can reduce the influence of ammonia's low combustibility to a certain extent.

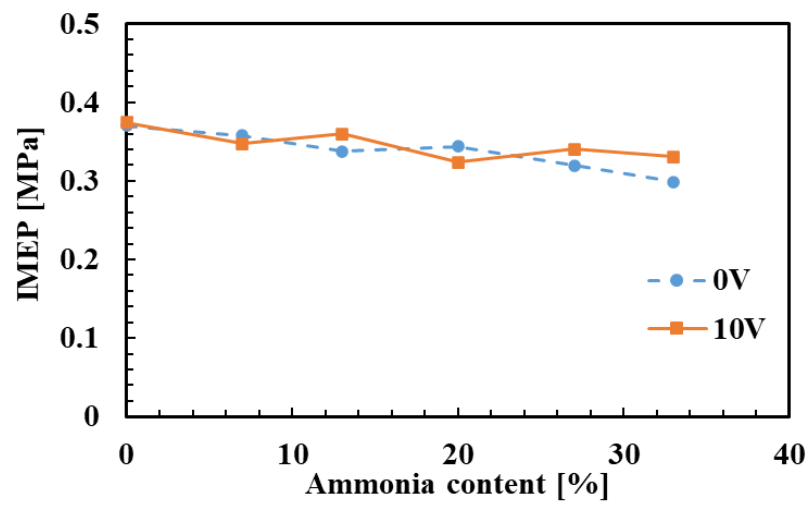

Fig. 9 Influence of glow plug voltage and gasoline and ammonia mixture ratio on IMEP $(\lambda=1.3)$

As shown in Fig. 10, the glow plug voltage has almost no effect on the COV(IMEP) variation range in the gasoline/ammonia mixture combustion experiment. Under all experimental conditions, the COV (IMEP) of the engine is lower than $10 \%$, so the engine can be regarded as running smoothly. However, compared with not using the glow plug, when the glow plug voltage is $10 \mathrm{~V}$, the fluctuation of COV(IMEP) caused by the change of the mixing ratio is gentler.

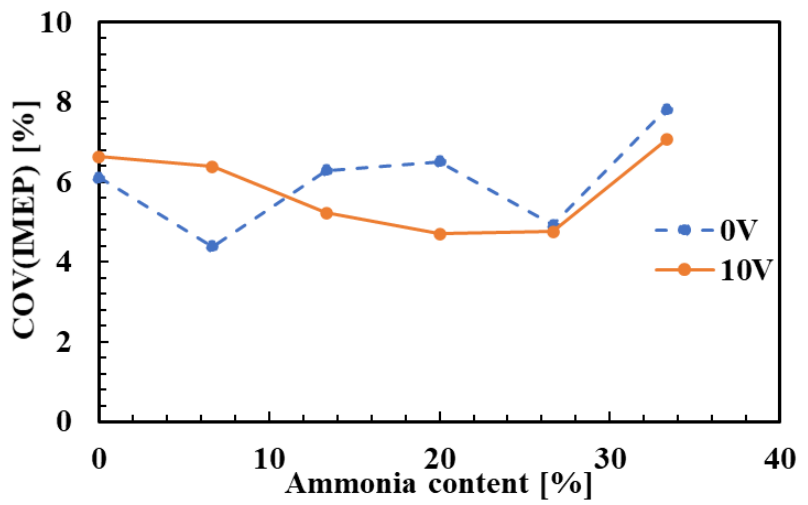

Fig. 10 Influence of glow plug voltage gasoline and ammonia mixture ratio on $\operatorname{COV}(\mathrm{IMEP})(\lambda=1.3)$

Unlike the lean combustion experiment of gasoline because the fuel contains ammonia in the co-combustion experiment, the NOx in the exhaust gas was also include NOx generated by ammonia combustion (fuel NOx) in addition to thermal NOx. The condition that the ammonia content is $0 \%$ is used as the reference condition that the fuel only used gasoline. It can be seen from Fig. 11, compared with the $0 \% \mathrm{NH}_{3}$ condition, $\mathrm{NOx}$ emissions decrease under the condition of $7 \% \mathrm{NH}_{3}$. There are two reasons. First, because ammonia gas is mixed in the fuel, the combustion temperature is reduced, so the thermal NOx is reduced. Second, due to the reduction reaction between unburned ammonia $(\mathrm{NH} 2, \mathrm{NH}$, $\mathrm{N})$ and $\mathrm{NO}^{(16)(17)}$ the thermal NOx is reduced. On the other hand, under the condition of $13 \% \mathrm{NH}_{3}$, there is a drastic increase in NOx emissions. The reason is considered to be that the quantity of the fuel NOx caused by ammonia is more than the quantity which can be reduced reacted by unburned ammonia $(\mathrm{NH} 2, \mathrm{NH}, \mathrm{N})$. And as shown in Fig. 11, the effect on glow plug is more obvious under the condition of ammonia content from $20 \%$ to $33 \%$. It can be inferred, under the relatively high ammonia content condition, the glow plug can promote combustion and reduce NOx emission.

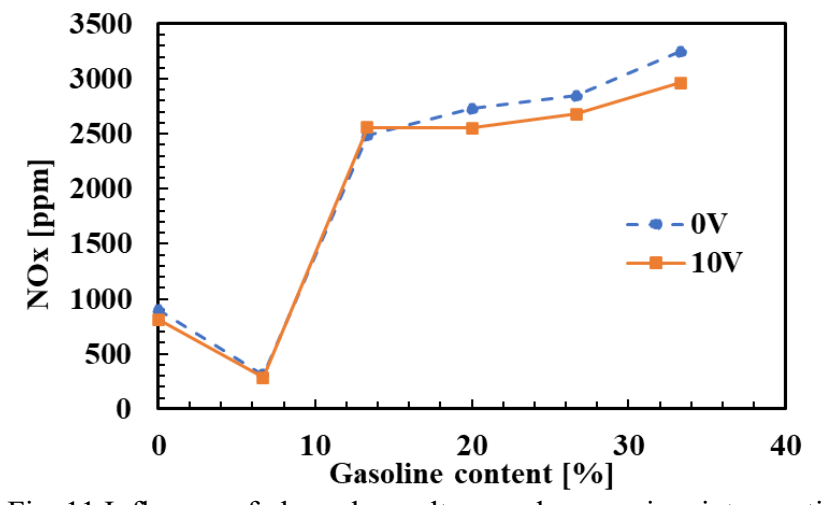

Fig. 11 Influence of glow plug voltage and ammonia mixture ratio on $\operatorname{NOx}(\lambda=1.3)$

\subsubsection{Influence of excess air ratio on combustion}

The influence of excess air ratio on mass fraction burned under the condition of $33 \% \mathrm{NH}_{3}$ is shown in Fig. 12. As the excess air coefficient decreases (the fuel concentration increases), the slope of the curve gradually increases, indicating that the fuel combustion speed in the cylinder increases, lowering the combustion period. And the rising time of the curve is advanced, with the fuel concentration increases, which shows that increasing fuel concentration helps ignition. As the combustion speed 


\section{Bin Guo et al. / International Journal of Automotive Engineering}

Vol.13, No.1(2022)

increases, when the excess air ratio changes from 1.3 to 1.1 , the corresponding combustion periods are $30 \mathrm{deg}$., $22 \mathrm{deg}$. and $18 \mathrm{deg}$.

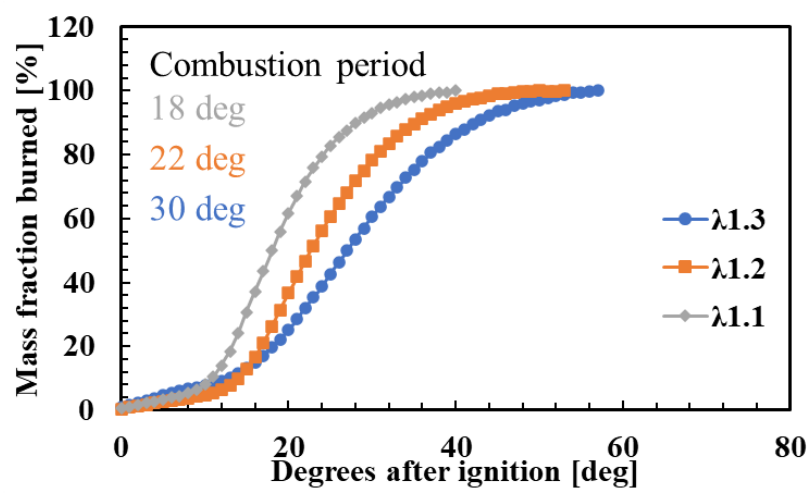

Fig. 12 Influence of excess air ratio on mass fraction burned $\left(33 \% \mathrm{NH}_{3}\right)$

As shown in the Fig.13, from condition $\lambda 1.3$ to $\lambda 1.1$, the IMEP increased because the fuel supplied increased due to the decrease in excess air ratio. For thermal efficiency, from condition $\lambda 1.3$ to $\lambda 1.2$, the thermal efficiency increase, although compared with $\lambda 1.3$ the specific heat ratio is lower, the combustion temperature is higher and the percentage burned (the ratio of actual quantity of mixture burned and fuel supply quantity) is lower under condition $\lambda 1.2$, which will cause a decrease in thermal efficiency. But with the decrease of excess air ratio, the combustion period shortening, the degree of constant volume increase, which play a leading role, cause the thermal efficiency is improved from $\lambda 1.3$ to $\lambda 1.2$. As shown in Fig.13, from condition $\lambda 1.2$ to $\lambda 1.1$ the thermal efficiency decreased slightly. Under the $\lambda 1.1$ compared to the increase in thermal efficiency caused by shortened the combustion period and the degree of constant volume increase, due to the decreased indicate work caused by decreased specific heat ratio, and increased cooling loss caused by increased combustion temperature, the thermal efficacy was slightly reduced. When the excess air ratio changes from 1.3 to 1.1 , the corresponding COV(IMEP) are $7.8 \%, 3.5 \%$, and $4.3 \%$.

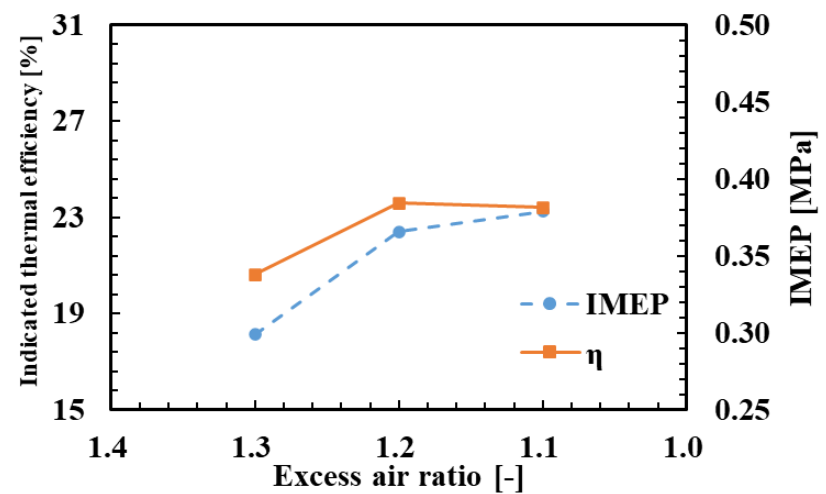

Fig. 13 Influence of excess air ratio on IMEP and indicated thermal efficiency $\left(33 \% \mathrm{NH}_{3}\right)$

\section{Conclusions}

Engine performance studies for lean combustion and gasoline/ammonia/air co-combustion have been conducted. Through research, the following conclusions are reached:
For lean combustion experiments:

1. The use of glow plugs has no obvious effect on improving the IMEP and thermal efficiency of the engine under the ignition condition retarded less than $5 \mathrm{deg}$. BTDC. On the other hand, using the glow plug can improve the IMEP and thermal efficiency of the engine under the ignition condition advanced more than $5 \mathrm{deg}$. BTDC.

2. Combining the sub-chamber structure and high compression ratio, the combustion period of the SI engine can be greatly shortened. For $\lambda=1.82$, the MBT combustion period is $30.7 \%$ shorter than that of the ordinary combustion period SI engine.

3. With the ignition timing is retarded, thermal NOx emission is significantly reduced.

For gasoline/ammonia co-combustion experiments:

1. Under certain conditions of excess air ratio, as the ammonia content increases (gasoline content decreases), the combustion period increases, and the combustion heat release decreases, which makes the peak combustion pressure drop.

2. Under certain conditions of excess air ratio, as the ammonia content increases, the IMEP curve of both glow plug voltage conditions shows almost a decreased tendency. It is estimated that the change in NOx emission with the increase in ammonia content is effect by temperature and the reduction reaction between $\mathrm{NH} 2, \mathrm{NH}, \mathrm{N}$ and $\mathrm{NO}$.

3. Under the conditions of the experimental excess air ratio $(\lambda=1.1-1.3)$, the engine can run under the condition of the fuel mixture ratio is $33 \% \mathrm{NH}_{3}$, the $\mathrm{COV}$ (IMEP) was $7.8 \%, 3.5 \%$ and $4.5 \%$ when changed excess air ratio to $\lambda 1.3, \lambda 1.2$ and $\lambda 1.1$. With a decrease in excess air ratio $(\lambda 1.3$ to $\lambda 1.1)$ the IMEP increased. On the other hand, the thermal efficiency increased firstly and then decreased slightly.

This paper is written based on a proceeding presented at 2021 JSAE Congress (Autumn) held online from 13 October to 15 October 2021.

\section{Acknowledgments}

This work was supported by Japan Society for the Promotion of Science, Grants-in-Aid for Scientific Research (No.19K04244) and Sophia University Special Grant for Academic Research, Research in Priority Areas.

\section{References}

(1) K. Hatamura: Promotion of Electric Vehicles and Measures to Reduce Well to Wheel CO2 Emissions of Vehicles, Engine Review, Society of Automotive Engineers of Japan, Vol. 9, No. 6, 2019

(2) Agency for Natural Resources and Energy, Japan: https://www.enecho.meti.go.jp/statistics/electric_power/ep00 2/pdf/2020/0-2020.pdf, accessed August 10, 2021

(3) M. Koike, H. Miyagawa, T. Suzuoki, K. Ogasawara: Ammonia as a Hydrogen Energy Carrier and Its Application to Internal Combustion Engines, Journal of the Combustion Society of Japan, Vol.58, No.184, pp.99-106, 2016, doi:https://doi.org/10.20619/jcombsj.58.184_99 


\section{Bin Guo et al. / International Journal of Automotive Engineering}

Vol.13, No.1(2022)

(4) I.M. Robertson, P. Sofronis, A. Nagao, M.L. Martin, S. Wang, D.W. Gross, K.E. Nygren: Hydrogen Embrittlement Understood, 2014 Edward DeMille Campbell Memorial Lecture ASM International, 2015, doi:10.1007/s11661-015-2836-1

(5) Y. Ashida, K. Arashiba, K. Nakajima, Y. Nishibayashi: Molybdenum-catalysed Ammonia Production with Samarium Diiodide and Alcohols or Water, Nature, Vol.568, pp.536540, 2019, doi:https://doi.org/10.1038/s41586-019-1134-2

(6) T. McSweeney, J. Holbrook: Ammonia Safety, 2006 Annual NH3 Fuel Conference, 2006, https://nh3fuelassociation.org/wpcontent/uploads/2012/05/battelle.pdf, accessed August 10, 2021

(7) M. Saka, M. Kiya, T. Irie, H. Yakuwa: Study of Stress Corrosion Cracking Test Method for Pure Copper Tube in Ammoniacal Environment, Zairyo-to-Kankyo, Vol.65, No.4, pp.138-142, 2016, doi:https://doi.org/10.3323/jcorr.65.138

(8) K. Takizawa, A. Takahashi, K. Tokuhashi, S. Kondo, A. Sekiya: Burning Velocity Measurements of Nitrogencontaining Compounds, Journal of Hazardous Materials, Vol.155, No.1-2, pp.144-155, 2008, doi:10.1016/j.jhazmat.2007.11.089

(9) A. Hayakawa, T. Goto, R. Mimoto, Y. Arakawa, T. Kudo, H. Kobayashi: Laminar Burning Velocity and Markstein Length of Ammonia/Air Premixed Flames at Various Pressures, Fuel, vol. 159, pp. 98-106, 2015, doi: https://doi.org/10.1016/j.fuel.2015.06.070

(10) S. Ratnak, J. Kusaka, and Y. Daisho: Experiments and Simulations of a Lean-Boost Spark Ignition Engine for Thermal Efficiency Improvement, SAE International Journal of Engines, Vol.9, No.1, pp.379-396, 2016

(11) Y. Takashima, H. Tanaka, T. Sako, M. Furutani: Evaluation of Engine Performance by Changing Specification of Prechamber Spark Ignition Plug under Lean Burn Condition, Transactions of Society of Automotive Engineers of Japan, Vol.45, No.2, pp.221-227, 2014, doi: https://doi.org/10.11351/jsaeronbun.45.221

(12)H. Nakano, S. Kobayashi, T. Sako, K. Nishimura, T. Ishiyama: Research on Effect of Sub-chamber in Natural Gas Lean-burn Engine -Thermal Efficiency Improvement of Natural Gas Engine-, Transactions of Society of Automotive Engineers of Japan, Vol.47, No.4, 2016, doi: https://doi.org/10.11351/jsaeronbun.47.843

(13)L. Nemoianu, C. Pana, N. Negurescu, A. Cernat, D. Fuiorescu, C. Nutu: Study of the Cycle Variability at an Automotive Diesel Engine Fueled with LPG, MATEC Web of Conferences, Vol.112, Paper No.10006, 2017, doi: https://doi.org/10.1051/matecconf/201711210006

(14) Y. Urata, J. Takanashi: Study of Gasoline-fueled HCCI Engine, Journal of the Combustion Society of Japan, Vol.51, No.155, pp.40-47, 2009, doi: https://doi.org/10.20619/jcombsj.51.155_40

(15) Y. Nakajima, S. Fukada, Gasoline Engine for Automobiles, p.88-89, 1988
(16) H. Kobayashi, A. Hayakawa: Carbon-free Ammonia Combustion, Journal of the Combustion Society of Japan, Vol.58, No.183, pp.41-48, 2016, doi: https://doi.org/10.20619/jcombsj.58.183_41

(17) A. Hayakawa, T. Goto, R. Mimoto, T. Kudo, H. Kobayashi: NO Formation/Reduction Mechanisms of Ammonia/Air Premixed Flames at Various Equivalence Ratios and Pressures, Mechanical Engineering Journal, Vol.2, No.1, Paper No.14-00402, 2015, doi: https:// doi.org/10.1299/mej.14-00402 